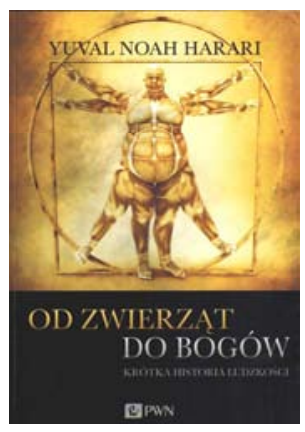

\title{
Leszek Mrozewicz (Gniezno)
}

\section{NAJWIĘKSZE OSZUSTWO HISTORII}

Yuval Noah Harari, Od zwierząt do bogów. Krótka historia ludzkości, tłum. Justyn Hunia, Dom Wydawniczy PWN, Warszawa 2014, 518 s. + wkładka z ilustraciami

Historia zakpiła z człowieka. Wyrwała go ze stanu względnej pomyślności, zdrowej diety, nieskomplikowanych relacji międzyludzkich i prostego widzenia świata, i zmusiła do pokonywania niewyobrażalnych wprost barier. Co prawda przy okazji stworzyła mu szansę osiągnięcia niezwykłych możliwości, ale jednocześnie przyniosła ryzyko samozagłady. A wszystko zaczęło się w chwili, gdy Homo sapiens porzucił zbieraczo-łowiecki tryb życia na rzecz uprawy roli i udomawiania zwierząt.

Swego czasu uczeni ogłosili, że rewolucja agrarna była dla ludzkości ogromnym krokiem naprzód (...). Opowieść tę należy włożyć między bajki. (...) Zamiast zaprowadzić nową erę pomyślności, (...) przyniosła rolnikom żywot przeważnie trudniejszy i mniej satysfakcjonujący niż egzystencja zbieraczy-łowców. Rewolucja agrarna z pewnością pomnożyła zasoby żywnościowe pozostające do dyspozycji człowieka, ale większa ilość żywności nie przekładała się na lepszą dietę czy czas wolny. Przyniosła raczej eksplozje demograficzne i rozpasanie elit. Przeciętny rolnik pracował ciężej niż typowy zbieracz-łowca, a w nagrodę dostawał gorsze pożywienie. Rewolucja agrarna była największym oszustwem historii (s. 106, podkr. L. M).

Harari idealizuje czasy przedneolityczne. Sugeruje, że byt zbieracko-łowiecki był dla człowieka swoistego rodzaju błogostanem.

Przez dziesiątki tysięcy lat przedstawiciele homo sapiens nie wtrącali się (...) w życie innych zwierząt (...), wciąż czerpali środki przetrwania ze zbieractwa roślin i polowania na dziką zwierzynę. Czy jest sens robić coś innego, kiedy przyjęty sposób życia zapewnia dostatek pożywienia i podtrzymuje bogate uniwersum struktur społecznych, wierzeń religijnych i procesów politycznych? Wszystko zmieniło się około 10 tysięcy lat temu, kiedy homo sapiens zaczęli niemal cały swój czas i energię wydatkować na 
manipulowanie warunkami życiowymi kilku wybranych gatunków roślin i zwierząt. (...) Wychodzili z założenia, że ich praca zapewni im więcej owoców, ziarna i mięsa. Oto jak w sposobie życia ludzi dokonała się istna rewolucja - rewolucja agrarna (s. 103-104).

Rewolucja agrarna (neolityczna) doprowadziła jednak do zmian, które przesądziły o dalszym rozwoju ludzkości i doprowadziły do dzisiejszego jego stanu. Przede wszystkim wymogła myślenie o przyszłości, co wcześniej, uważa Harari, było całkowicie zbędne. Rolnik musiał zacząć przewidywać skutki zdarzeń atmosferycznych, planować zasiewy, przezornie budować kanały i studnie. Mógł więc także wpływać na kształt tej wyobrażanej przez siebie przyszłości. Z kolei zaś „stres związany z uprawą ziemi miał dalekosiężne skutki. Był fundamentem wielkich systemów politycznych i społecznych" (s. 129). Szybko też się okazało, że rolnik musi pracować na utrzymanie tych systemów i tworzących się elit. Jemu samemu pozostawiano tylko minimum potrzebne do przetrwania. Ale to właśnie

te zawłaszczane nadwyżki żywnościowe były motorem historii i cywilizacji. Napędzały politykę, wojny, sztukę i filozofię. Wznosiły pałace, twierdze, pomniki i świątynie. Aż do epoki ponowoczesnej przeszło 90 procent ludzi było rolnikami (...). Wytwarzane przez nich nadwyżki karmiły wąską mniejszość - królów, funkcjonariuszy aparatu władzy, żołnierzy, duchownych, artystów i myślicieli - która zapełniła podręczniki historii. Historia to opowieść o tym, co garstka ludzi robiła w czasie, gdy cała reszta ludzkości orała pola i nosiła wodę (s. 130).

Poza warunkami biologicznymi ludzi od świata zwierząt odróżnia umiejętność wspólnego działania. „Pomimo braku takich instynktów biologicznych, w epoce łowiecko-zbierackiej setki nieznających się ludzi potrafiło ze sobą współpracować” (s. 131). Podstawą porozumienia były mity -

silniejsze, niż można było przypuszczać. Gdy rewolucja agrarna stworzyła przesłanki do powstania zatłoczonych miast i silnych imperiów, ludzie zaczęli wymyślać opowieści o potężnych bogach, ojczyznach i spółkach akcyjnych. Gdy ewolucja człowieka posuwała się sobie właściwym tempem, ludzka wyobraźnia budowała zdumiewające sieci masowej współpracy niepodobne do niczego, co znał świat (s. 131/132).

Owe „sieci współpracy” autor określa terminem „porządek wyobrażony”, w którym ukonstytuowane normy społeczne nie były następstwem głęboko zakorzenionych instynktów czy też stosunków towarzyskich, ale wyznawania tych samych mitów (s. 133). Takim mitem jest na przykład przekonanie o istnieniu uniwersalnych i odwiecznych zasad sprawiedliwości jak równość czy hierarchia. 
Lecz jedynym miejscem, w którym takie uniwersalne zasady istnieją, jest płodna wyobraźnia homo sapiens oraz mity, jakie wymyślają i sobie opowiadają. Zasady te nie mają wartości obiektywnej (s. 137).

W konsekwencji zaś w jakiś porządek wierzymy nie dlatego,

że jest obiektywnie prawdziwy, ale dlatego, że wierzenie weń umożliwia nam owocną współpracę i budowanie lepszego społeczeństwa. Porządki wyobrażone nie są niecnymi spiskami ani czczymi mrzonkami. Są raczej jedynym sposobem, w jaki wielka liczba ludzi może ze sobą skutecznie współpracować (s.140).

Porządek wyobrażony jest jednak kruchy, łatwo może upaść, tworzą go bowiem mity, te zaś znikają - wystarczy, że przestaniemy w nie wierzyć.

Ale to jednak płodna wyobraźnia zadecydowała, że Homo sapiens przetrwał i podbił świat. „Od porządku wyobrażonego nie ma ucieczki” (s. 150), to właśnie on zdeterminował postawę ludzkości i jej dzieje. Dzięki niemu na wszystkich kontynentach rozwijały się „handel, imperia i religie uniwersalne”, doprowadzając w rezultacie do powstania dzisiejszego zglobalizowanego świata. To porządki wyobrażone wytworzyły jedno zglobalizowane społeczeństwo (s. 287).

Książka jest fascynująca, wprowadza nas bowiem w świat rozważań o niespotykanym wymiarze. Autor pokazuje, jak człowiek wyodrębnił się ze świata zwierząt i jak zaczął budować swój własny, niszcząc przy okazji ekosystem, z którego wyszedł. Zastanawia się nad przyczyną sukcesu Homo sapiens, a nie - na przykład - neandertalczyka, roztacza wizję różnych „porządków wyobrażonych" w odległych częściach świata, próbując odpowiedzieć na pytanie, dlaczego między nimi z reguły nie dochodziło do interakcji. Inkowie mieli na tyle mgliste pojęcie o istnieniu państwa Azteków, że upadek azteckiego imperium dokonał się zupełnie poza ich świadomością. Wyprawy chińskiego admirała Zheng He (1405-1433) nie miały doprowadzić do podboju i kolonizowania ziem, do których docierał. Jego odkrycia nie pociągnęły za sobą żadnych tego typu konsekwencji, nie wzbudziły też specjalnych emocji. Większość władców Chin nie była zainteresowana nawet Japonią (s. 350-351). Wolę poznania - i podboju - innych rejonów globu ziemskiego wyzwolili w sobie jedynie Europejczycy, doprowadzając w konsekwencji do dominacji ich kultury na większości kontynentów. To właśnie Europejczycy uczucie niewiedzy przekształcili w pasję odkrywania i badania nieznanych dotąd obszarów, a zarazem uczynili ją - niewiedzę - motorem nieskrępowanych badań naukowych. Doprowadziło to do rewolucji naukowej, która rozpoczęła się u zarania wieku XVII i która trwa do dzisiaj, całkowicie przebudowując wyobrażenie o miejscu człowieka we wszechświecie. Paradoksal- 
nie spowodowało ją pozyskanie świadomości, że ludzkość pozostaje w odmętach niewiedzy, a to dlatego, że wiedza, która wykraczałaby poza to, co człowieka otaczało i poza utrwaloną tradycję, zawartą w świętych księgach, dotąd nie była mu do niczego potrzebna. Dysponowano wiedzą o tym, co było tej wiedzy warte, na zwątpienie nie było miejsca. Wątpiący nie mieli zresztą głosu. Konsekwentny ciąg rozwojowy doprowadził Homo sapiens do zdominowania świata i do zdobycia przez niego takiej wiedzy, dzięki której osiągnął niebywale możliwości technologiczne. To dzięki nim postawił stopę na Księżycu, ale też dzięki nim wytworzył najgroźniejsze narzędzie samozagłady - bombę atomową. Wniosek z tego, uważa Harari, jest jednoznaczny: uczmy się na własnych błędach.

Badamy historię nie po to, by odgadywać przyszłość, ale by poszerzać nasze horyzonty, uzmysławiać sobie, że panujący stan rzeczy nie jest ani naturalny, ani nieunikniony, i że w konsekwencji mamy przed sobą znacznie więcej możliwości, niż sobie wyobrażamy (s. 292).

Angielskojęzyczna wersja książki ukazała się w roku 2012, a już dwa lata później (2014) doczekała się wersji polskiej. Świadczy to bardzo dobrze o nadążaniu Domu Wydawniczego PWN za trendem światowym, książka stała się bowiem bestsellerem i doczekała przekładu już na ponad 30 języków. Warto też podkreślić, że polską wersję czyta się bardzo dobrze, przekład jest sprawny, żywy, co nie znaczy, że całkowicie wolny od potknięć. W wielu miejscach wymagałby korekty stylistycznej. Kompromituje zła odmiana słowa „cywile”: zamiast *cywili powinno być cywilów (por. s. 192: „nad społeczeństwem cywili”!). Tłumacz nadmiernie stosuje spójnik „iż” (a już zawsze „mimo iż”!), zapominając, że jest on

nadużywany w języku potocznym i stylu dziennikarskim zamiast neutralnego: $z$ e. Spójnika iż można używać, żeby uniknąć kilkakrotnego powtórzenia spójnika $\dot{z} e \mathrm{w}$ jednym zdaniu. W innych wypadkach używanie tego spójnika jest manieryczne i pretensjonalne” (za: „Słownik poprawnej polszczyzny").

Karygodnym i niewytłumaczalnym błędem autora jest datowanie (zob. s. 361) inskrypcji naskalnej z Behistun na „około 5600 p.n.e.” (sic!): powstała ona za panowania i z polecenia króla perskiego Dariusza I (522-486 p.n.e.), prawdopodobnie w latach 520-518 p.n.e.

Zakładam, że książka znajdzie odzew wśród bardzo szerokiego kręgu czytelników. Powinna też zająć poczesne miejsce w kształceniu akademickim, zwłaszcza na kierunkach humanistycznych i społecznych. 